\title{
出水時における河道内樹木の破壊規模の 予測に関する基礎的研究 \\ BASIC STUDY ON THE PREDICTION OF EXTENT OF TREE DESTRUCTION IN RIVER CHANNEL BY FLOOD
}

\author{
砂田憲吾 $^{1} \cdot$ 河野逸朗 $^{2} \cdot$ 田中総介 ${ }^{3}$ \\ Kengo SUNADA, Itsuro KONO and Sousuke TANAKA \\ ${ }^{1}$ 正会員 工博 山梨大学教授 工学部土木環境工学科 ( $\bar{T} 400-8511$ 甲府市武田 4-3-11) \\ 2 非会員 工修 国土交通省関東地方整備局関東技術事務所（广273-0002 船橋市東船橋 5-2-1） \\ 3 学生会員 山梨大学大学院 工学研究科 (广400-8511 甲府市武田 4-3-11)
}

\begin{abstract}
Vegetation in river plays many important roles in the river environment. On the other hand, the destruction of the vegetation, especially tree, in river channel may cause a serious situation of driftwood in high water stage. In order to predict such disaster in river channel, the destruction condition of tree in flood flow should be investigated. In this paper, results of a preliminary examination on a simple method for prediction of the tree destruction are presented. At first, the destruction patterns of tree are classified and discussed. In the next, percentage of the destruction portion in the two cases of assumption of rectangular and actual shape in each cross section along the Fuji River are calculated by using a simple model. At last, the calculated distribution of percentages of destruction areas are compared with the damaged area obtained from field data of the Fuefuki River. Results of the analysis show that the simple model has fairly high possibility of estimating destruction area of tree in river.
\end{abstract}

Key Words : river planning, river environment, vegetation in river, tree destruction,

\section{1.はじめに}

治山・砂防事業の進渉などにより，河川上流地域にお ける土砂生産量・土砂流出量が減少している. またダム や堰などの下流域では流量の平滑化がもたらされている. その結果大規模出水・土砂移動機会の減少が顕著となり, 多くの河川で低水路部の河床低下および自然高水敷化と 共に植生の繁茂と樹林化が進んでいる. こうして形成さ れる河川植生は, 逆に流況や河道地形に影響を及ぼす一 方で，河川及び周辺地域の生態系の中心的存在であり， 河川環境の重要な環境要素の一つでもある. 河川管理の 立場から河川植生についての実態把握やそれらの変化を 明らかにすることは重要で, これまでに多くの調查研究 が行われている1，2)，3，4).

ところで，樹林化した植生は出水時における河積阻害 による水位の上昇や樹木根系の侵入による堤体の弱体化 などをもたらす，さらに，ある一定の流量を超えると， 樹木の破壊・逸脱が生じ流木となって橋脚などの箇所で 河道を閉塞し汇濫などこれまで以上に重大な被害を引き
起こす間接の原因となり得る. 出水時における河道内樹 木の破壊の条件と規模の予測について系統的な検討を行 う必要性がある．河道内の樹木の破壊についてはこれま でにもいくつかの調查研究がある。例えば，苅住 ${ }^{5}$ は樹 木の抜根試験を行い根の支持力を調べており, 渡邊ら は出水後の樹木の倒壊状況を詳しく調查している. さら に, 石川 》は流水に及ぼす葉面も含めた樹木の抵抗の定 量化を試みている。

本研究では, 河辺林の耐破壊性, 耐侵食性などに関す る他の研究者を含めた既往の研究成果を集約して, 河道 全体の総合的樹林管理の視点から河道内樹木の破壊の程 度を予測する手法の開発をめざした．まず，河道内にお いて考えられる樹木破壊の形態を分類・定義した後, 代 表的な破壊形態の場合に注目し, 平均的な取り扱いで, 破壊に至る出水時の最小流量を推定し, 考察する. 続い て, 水位の各段階に応じて, 横断面形状の違いや樹木抵 抗の仮定の違いを考慮して, 樹木に作用する流体力及び 破壊の推定限界值を求め, それらから断面ごとの破壊断 面率(破壊に至る横断方向区分面積の比率) を算定した. 


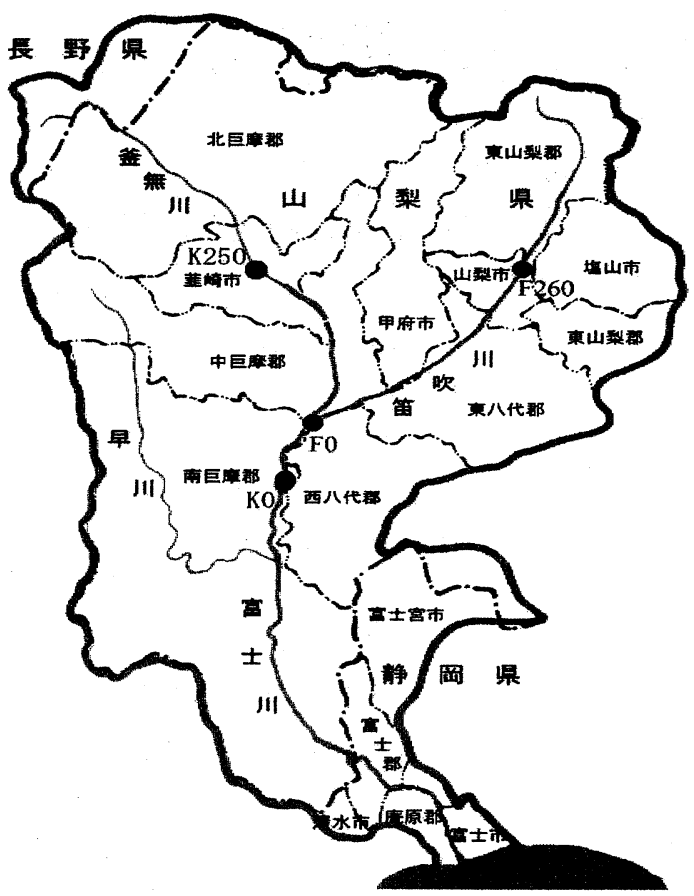

図-1 対象事例富士川

これらの計算結果と富士川支川笛吹川における’ 98 年 の出水により破壊した樹木の状況とを間接的に比較し， 検討した。

本研究の立場：この種の研究では，単一の樹木を対象 とする場合に比べ，より多くの不明確な要素が関係して くる. 樹木の種類, 樹齢もしくはスケール，樹木の耐破 壊特性，季節，河床材料特性，河床形態およびそれに伴 う澪筋の変遷，などがそれである。ここでは，これらの うち代表的かつ基本的な要素を取り上げ，できるだけ簡 潔な扱いで樹木破壊の全体を記述する枠組みを把握した いと考えている.

\section{2. 河道内樹木の破壊条件について}

対象とした河川は富士川の本川釜無川，支川笛吹川， 樹種が樹齢 4 歳のカワヤナギである. 図ー 1 に対象事例 の富士川流域を示寸 F260，K250 は上流域，F0，K0 は下 流域を示す。ここでは，まず単純な扱いとして長方形幅 広断面を仮定し流量 $\left(Q\left[\mathrm{~m}^{3} / \mathrm{s}\right]\right)$ をパラメータとして樹 木の破壊の検討を行った。 また, 出水時の水深平均流速 $(\bar{v}[\mathrm{~m} / \mathrm{s}])$ ，水深 $(h[\mathrm{~m}])$ は $Q$ を用いて等流条件から 与えた.

\section{（1）破壊形態の分類・定義}

植生は出水時には河道内の繁茂位置, 出水の程度など により様々な破壊が起こり得る．単木として河道内にお ける樹木の破壊を図一 2 のように 6 種類に分類・定義し た.これらのうち, 本研究では第一段階として, 倒伏, 抜根の場合に限定して検討することにした，倒伏，抜根
折 損 : 出水前の立木の状態から, 水に浸かり流水の作 用により，樹幹根元で折れてしまう破壊

倒伏: 破壊前までは折損と同様で, 破壊の際に樹幹が 折れずに曲がった状態になる破壊

抜 根: 樹木が倒伏して流水に浸かっている状態で, 流 体力の作用で河床から抜けてしまう破壊

周辺洗掘 : 倒伏した状態から樹木根元で周辺が洗掘され, 根の先端の深さ付近まで掘れて破壊

侵食流去: 出水量が多くなると流砂の洗掘, 堆積に伴う河 床の変動が起こる．流水により河床が削られ て，河床が低下し樹木が流木となる破壞 土砂堆積: 河床変動の堆積が生じる領域で, 樹木が倒伏し た状態で土砂がある程度堆積して破壊

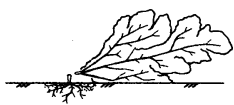

折損

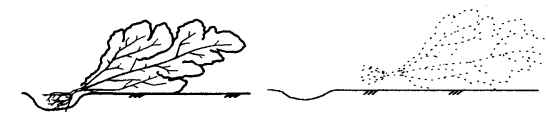

周辺洗掘

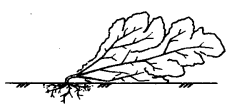

倒伏

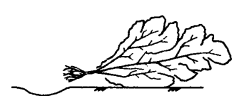

抜根

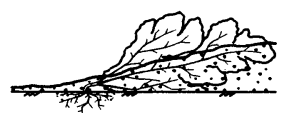

土砂堆積

図-2 樹木の破壊形態の分類 - 定義

の破壊形態は，河道状況が示す流れの作用と樹木の抵抗 との関係を反映している代表的なケースであると考えら れる。

\section{（2）破壊の作用值}

破壊の作用值は出水時に流水の作用によって樹木が破 壊されるときの值である. 倒伏では図一3のように樹木 をモデル化し，固定片持ばりとして根元でのモーメント

$(M[\mathrm{~N} \cdot \mathrm{m}])$ を式（1）から求める。抜根では流水によ り樹木一本の受ける流水抵抗力 $(P[\mathrm{~N}])$ を, 石川 ${ }^{7} に$ よるカワヤナギの流水抵抗特性, 生長特性から式 (2) で 求める.

$$
\begin{aligned}
& M=\frac{1}{2} \eta \rho C_{D} \int_{0}^{h} v^{2}(y) y 2 r(y) d y \\
& P=0.00149 v^{-1.5}(1.24 Y-0.35)^{1.8} \\
& M=\frac{1}{2} \eta \rho C_{D} k^{2} \int_{0}^{h} 2 r(y) y^{\frac{9}{7}} d y
\end{aligned}
$$

$k=\frac{8 \bar{v}}{7 h^{\frac{1}{7}}}$

$\eta:$ 遮蔽率, $\rho:$ 流体の密度 $\left[\mathrm{N} \cdot \mathrm{s}^{2} / \mathrm{m}^{4}\right]$,

$C_{D}$ : 樹木の抗力係数, $v(y):$ 流速分布 $[\mathrm{m} / \mathrm{s}]$,

$2 r(y):$ 枝幅 $[\mathrm{m}], 2 r_{0}:$ 最大枝幅 $[\mathrm{m}]$ 


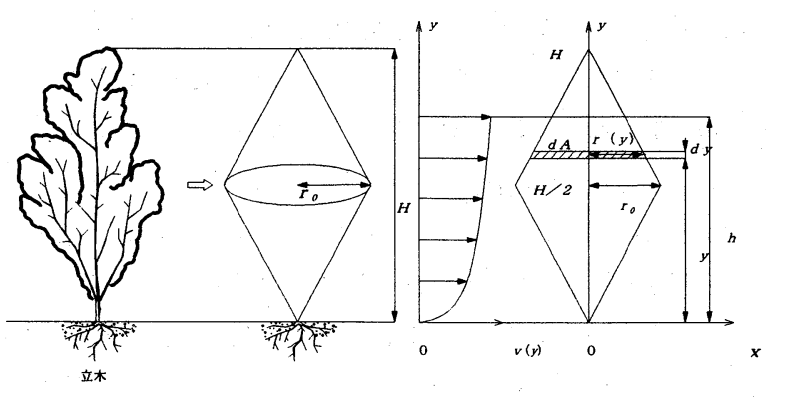

図-3 樹木のモデル化

\section{（3）破壊の推定限界値}

破壊の推定限界値は流水の作用によって樹木が耐える ここのできる限界の值である．倒伏では建設省河川局治 水課 ${ }^{8)}$ による樹木の引き倒し試験から，倒伏限界モーメ ント $\left(M_{C}[\mathrm{~N} \cdot \mathrm{m}]\right)$ を胸高直径 $\left(D^{\prime}[\mathrm{cm}]\right)$ より式 $(5)$ で求める. 抜根では苅住 ${ }^{5)}$ による樹木の抜根試験から, 根の支持力を根元直径 $(D[\mathrm{~cm}])$ より式 (6) で求める. また, $\mathrm{a}=2.5, \mathrm{~b}=0.016$ とした。

$$
\begin{aligned}
& M_{C}=a D^{\prime 2.0} \\
& P_{C}=b D^{1.65}
\end{aligned}
$$

$Y:$ 樹龄 [歳], $a:$ 定数, $b:$ 定数

\section{3. 河床横断面の形状を考慮した検討}

\section{（1）実河床横断面}

図－4に河床横断面図とそのモデル化を示す. 図中 （b）のように，これまでの研究で用いてきた長方形幅 広断面では, 全ての箇所に流れるため平均的な破壊条件 が全断面で算定される. 図中（a ）は実河床横断面図で, これに対して, 図中（c）のように実河床横断面を $10 \mathrm{~m}$ ずつに区切り, 各区間内で河床高の平均をとり階段状に モデル化した断面を考慮する.出水が起こったとき， c ) では集中して流れる箇所や全く流れない箇所があり, 長 方形幅広断面と比べると実河床横断面の形状を考慮した 場合, 全ての筒所で破壊は起こらずより現実的である.

\section{（2）破壊限界を与える最小流量の検討}

倒伏, 抜根による破壊の作用值及び破壊の推定限界值 から破壊限界を与える流量 $\left(Q_{\min }\left[\mathrm{m}^{3} / \mathrm{s}\right]\right)$ を推定した。 図－5に笛吹川における $Q_{\min }$ の場所的変化を示す.また， 図－6に地点と水路断面幅 $(B[\mathrm{~m}])$ ，水路床勾配 $(I)$ の関係を示す. 図ー5から倒伏の $Q_{\text {min }}$ は地点によって大 きな変動が見られない. 一方, 抜根の $Q_{\min }$ は中・下流域 から上流域になるにつれて小さくなっている。これは， 図－6から中・下流域に比べ上流域は水路断面幅が狭く, 水路床勾配が急勾配になるため, 上流域での平均流速が 速くなるためだと考えられる，そのことから抜根の $Q_{\min }$ は河道特性の影響を受けることがいえる.また，図一 5

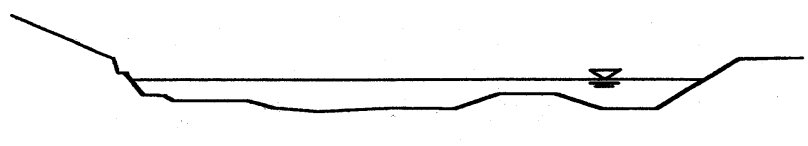

（a）実河床横断面図

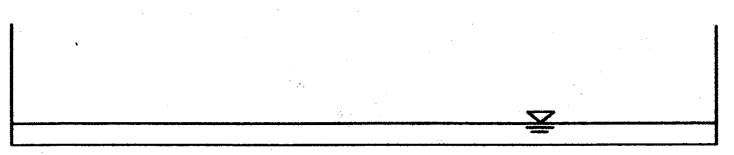

(b) 長方形幅広断面

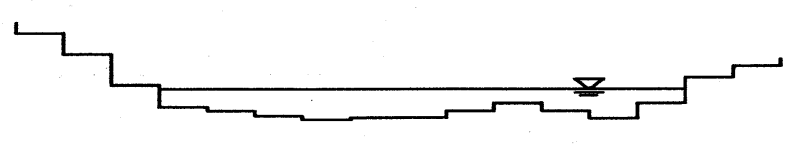

（c）モデル化した実河床横断面

図-4 河床横断面図とそのモデル化

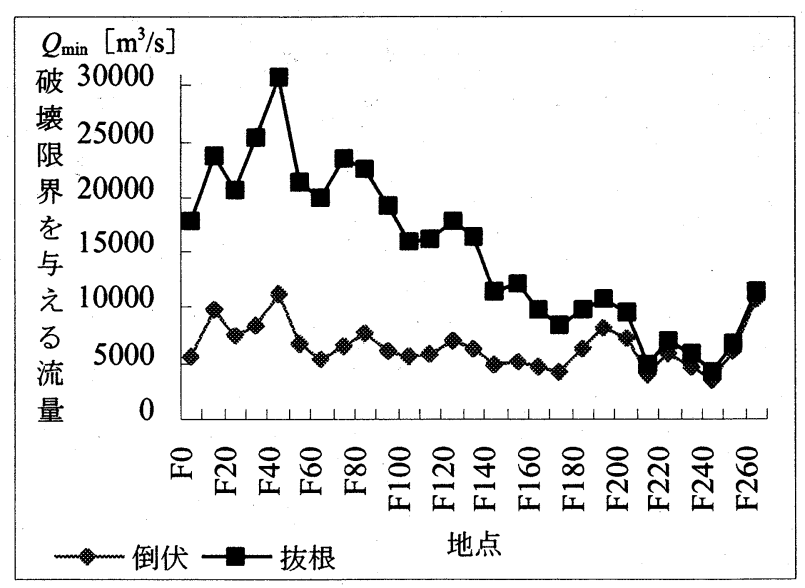

図-5 笛吹川での破壊限界を与える流量の流下方向の変化

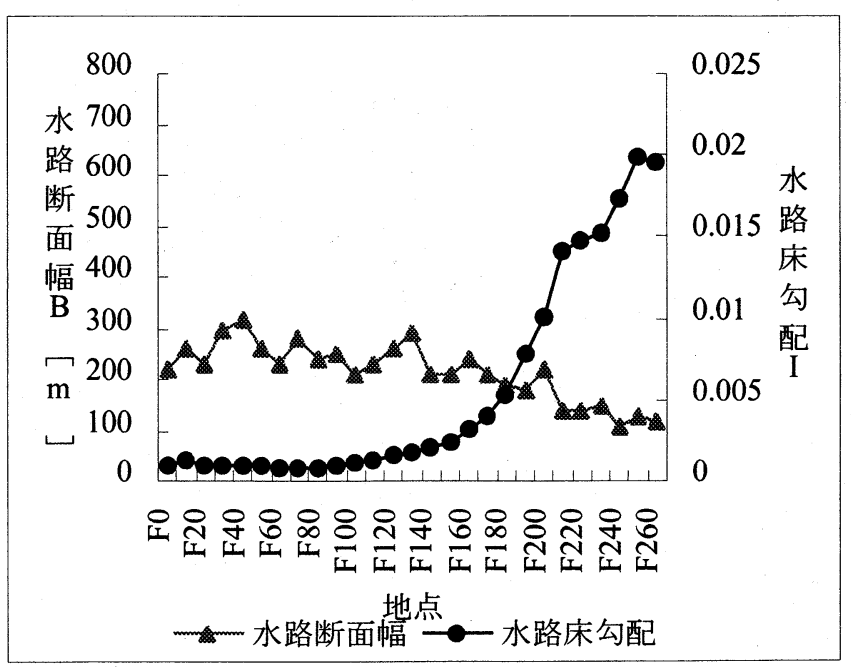

図-6 笛吹川での水路断面幅・水路床勾配の流下方向の変化

より，特に中，下流域において抜根は生じにくく，倒伏 が生じやすいことがわかる.

（3）実河床横断面の形状を考慮した 破壊の作用値の算定

次の諸条件をもとに倒伏，抜根による破壊の作用值の 


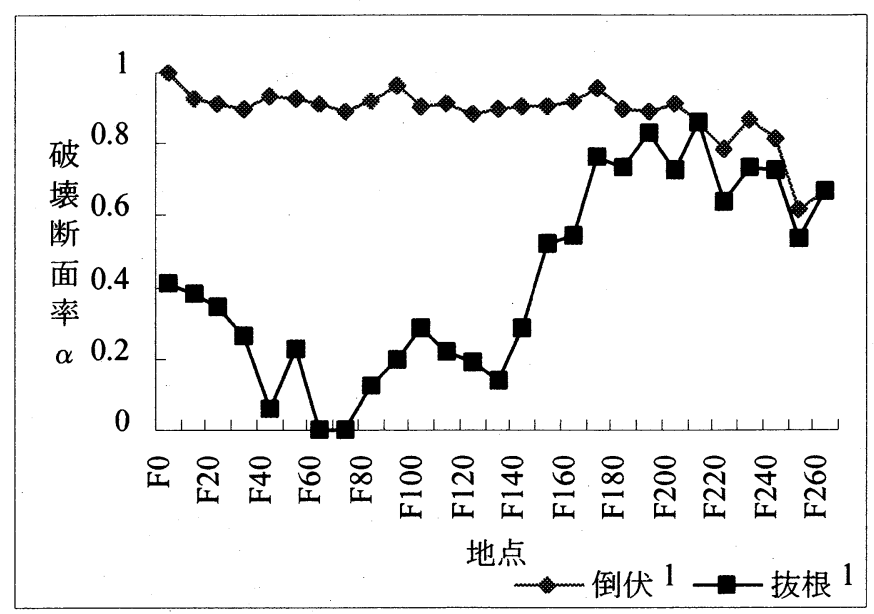

図-7 笛吹川での破壊率の流下方向の変化

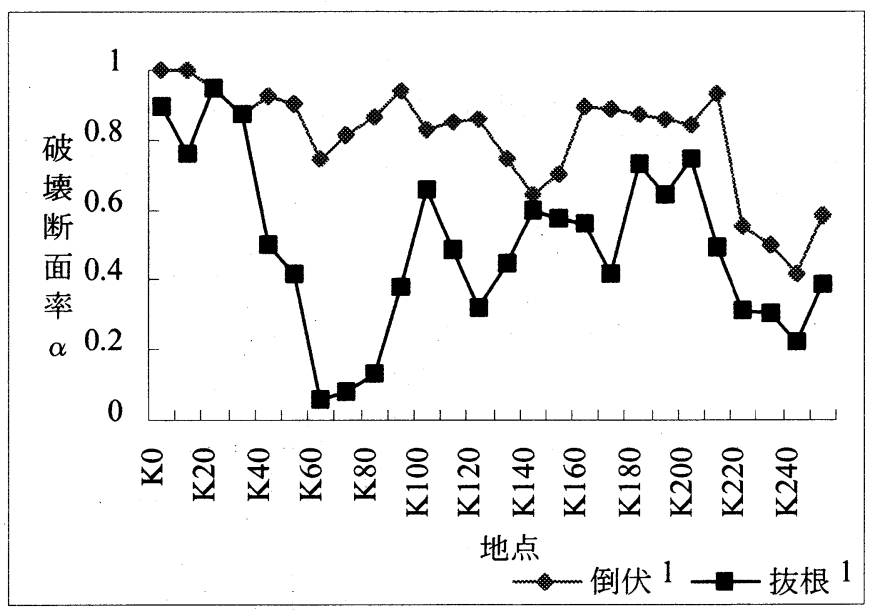

図-8＼cjkstart釜無川での破壊率の流下方向の変化

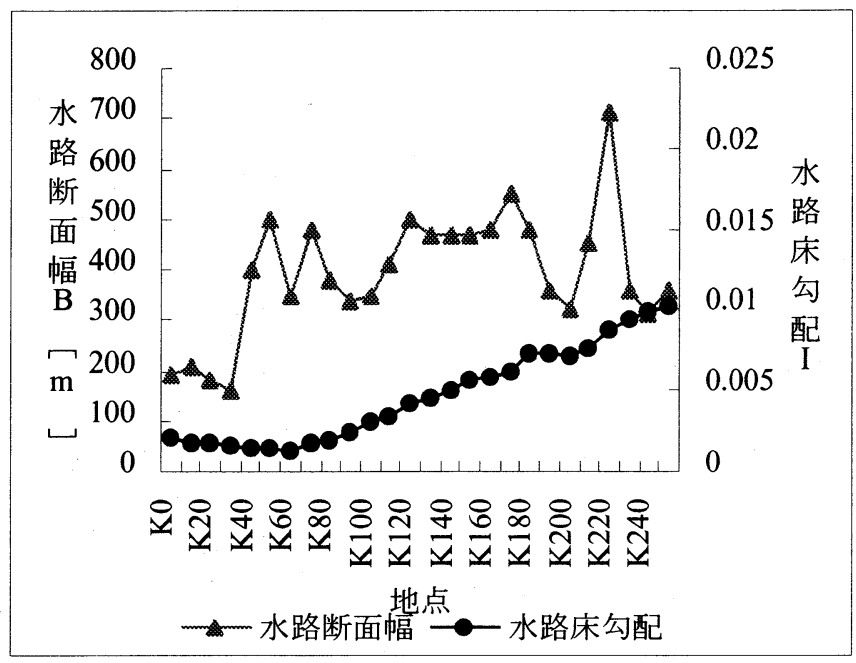

図-9 釜無川での水路断面幅・水路床勾配の流下方向の変化

算定を行う. 樹木は樹齢 4 歳のカワヤナギが平面的に平 均的に存在するとする. また, 等流で, ある流量を流し たときに隣り合う断面の周辺境界で生じる渦などによる エネルギー損失は無視する.

\section{a ) 笛吹川での樹木の破壊状況の検討}

笛吹川の地点（F0，F10， ‥, F260）の河床横断面を モデル化し, 計画高水流量 $\left(Q_{100}\left[\mathrm{~m}^{3} / \mathrm{s}\right]\right)$ のときの破壊
の作用値を算定する. 総断面数を $m$, 計画高水流量のと きに破壊した断面数を $m_{B}$ として, 地点と破壊断面率 ( $\alpha$ $=m_{B} / m$, 以降簡単に「破壊率」と呼ぶ）の関係を図一 7 に示す. なお, 計画高水流量は F0 F20 が $5800\left[\mathrm{~m}^{3} / \mathrm{s}\right]$, F30〜F90 が $4700 \quad\left[\mathrm{~m}^{3} / \mathrm{s}\right], \mathrm{F} 100 \sim \mathrm{F} 180$ が $3600 \quad\left[\mathrm{~m}^{3} / \mathrm{s}\right]$, F190 F 200 が $3200\left[\mathrm{~m}^{3} / \mathrm{s}\right], \quad \mathrm{F} 210 \sim \mathrm{F} 260$ が $1600\left[\mathrm{~m}^{3} / \mathrm{s}\right]$ である．笛吹川各地点の計画高水流量における破壊率に ついて，破壊の作用値で用いる算定式及び河道特性から 検討寸る. 図一6より，笛吹川の河道特性は富士川（釜 無川）合流地点 F0 から上流にかけて水路断面幅が狭く, 水路床勾配が急勾配になる傾向にある. 破壊の作用值は, 倒伏が式 (1), 抜根が式（2）より求める. 算定式から, 倒伏は流速, 水深に依存しているため, 倒伏の破壊率は 図ー7のように各地点においてあまりばらつきが見られ ない.一方, 抜根は流速のみに依存している. そのため, 上流域で流速は速くなり，破壊率も大きくなったと考え られる．これらのことから，破壊率は河道特性を反映し て変化することがわかる.

\section{b ）釜無川での樹木の破壊状況の検討}

笛吹川と同様に釜無川の地点（K0，K10，‥, K250） の河床横断面をモデル化し, 計画高水流量 $\left(Q_{100}\left[\mathrm{~m}^{3} / \mathrm{s}\right]\right)$ のときの破壊の作用値を算定し, 破壊率を求める，地点 と破壊率の関係を図一8に示す，なお，計画高水流量は $\mathrm{K} 0 \sim 50$ が $8800 \quad\left[\mathrm{~m}^{3} / \mathrm{s}\right], \mathrm{K} 60 \sim \mathrm{K} 200$ が $4000 \quad\left[\mathrm{~m}^{3} / \mathrm{s}\right], \mathrm{K} 210$ $\sim \mathrm{K} 220$ が $3000 \quad\left[\mathrm{~m}^{3} / \mathrm{s}\right], \mathrm{K} 230 \sim \mathrm{K} 250$ が $1700 \quad\left[\mathrm{~m}^{3} / \mathrm{s}\right]$ で ある. 図一8を見ると笛吹川において地点と破壊率の関 係を示した図一 7 と比べて，倒伏の破壊率が高く一定の 值を取ることや抜根の破壊率が上流域に行くほど高くな るというような規則性が見られない，そこで図ー9に釜 無川での地点と水路断面幅・水路床勾配の関係を示した. 笛吹川での地点と水路断面幅・水路床勾配の関係を示し た図一6では上流域に行くほど水路断面幅が狭くなり， 水路床勾配が急勾配となっていたが，図一9では，水路 床勾配は上流域に行くほど急にはなっているが，笛吹川 ほど大きく変化しておらず，また，水路断面幅は地点に よりばらつきが見られ，一概には言えないが，上流域に 行くほど広くなる傾向がある。そのために図ー8では倒 伏，抜根ともに地点によりばらつきが見られ規則性が見 られないのである。

\section{4. 横断方向運動量輸送·樹木群が存在する場合の 理論的考察}

\section{（1）複断面水路における横断方向運動量輸送 の数値計算}

前節までの検討では, 複断面水路の隣り合う断面の周 辺境界で生じる渦などによるエネルギー損失は無視して いる. ここでは, 複断面水路の隣り合う断面の周辺境界 のせん断力, 縦断方向の樹木の存在を考慮して樹木の破 壊率を検討する．複断面水路の小断面内は定常な等流の 
流れとして, 河床高さ, 粗度, 樹木による形状抵抗が横 断方向に変化する流れの基礎方程式を次式で表す9） 10 ).

$$
\rho g h I+\rho \varepsilon_{y z} h \frac{d^{2} u}{d z^{2}}-\rho u_{*}{ }^{2}-\rho C_{D} \lambda h \frac{u^{2}}{2}=0
$$

ここに, $g:$ 重力加速度 $\left[\mathrm{m} / \mathrm{s}^{2}\right], \varepsilon_{y z}:$ 水深平均横断方向 渦動粘性係数 $\left[\mathrm{m}^{3} / \mathrm{s}\right], u$ : 抵抗を考慮した水深平均流速 $[\mathrm{m} / \mathrm{s}], u_{*}$ : 摩擦速度 $[\mathrm{m} / \mathrm{s}], \lambda$ : 樹木の面積密度 $\left[\mathrm{m}^{-1}\right]$, $d z$ : 横断方向位置 である. $\varepsilon_{y z}$ は底面せん断と横断方 向拡散に依存し，次式で表される.

$$
\varepsilon_{y z}=\lambda_{0} u_{*} h
$$

ここに, $\lambda_{0}$ : 横断方向の拡散係数 であり, 数多くの研 究及び実験により得られている ${ }^{9)}$. その值は $0.08 \sim 0.179$ であり, 本研究では平均值の $\lambda_{0}=0.14$ を用いる.

u*は等流条件から次式で表される.

$$
u *^{2}=\frac{g n^{2} \bar{v}^{2}}{h^{1 / 3}}
$$

ここに, $n:$ 粗度係数 $\left[\mathrm{m}^{-1 / 3} \cdot \mathrm{s}\right]$ であり, $n=0.03\left[\mathrm{~m}^{-1 / 3}\right.$. s] とした. 入は図ー3のようなモデル化された樹木が, 複断面水路の平面積 $\left(B_{S} \times B_{S}\left[\mathrm{~m}^{2}\right]\right)$ の小断面内に平均的 に存在するときの密度で次式によって得る.

$$
\lambda=\frac{r}{B_{S}{ }^{2}} j
$$

ここに, $B_{S}$ : 小断面の幅 $[\mathrm{m}], r:$ モデル化された樹木 の円錐形底面の半径 $[\mathrm{m}], j$ : 小断面内に存在する樹木 の本数 [本] である. ここで， $B_{S}$ は図-4-（c）のモ デル化した実河床横断面を用いるため $10 \mathrm{~m}$ であり, 縌 断方向の幅も $B_{S}$ とした. したがって, $\lambda$ は小断面に樹木 が $j$ 本平均的に存在するときの密度となる. 計画高水流 量のときの流速を式 (7) より求め, 水深平均流速とその ときの $h$ から倒伏，抜根における破壊の作用値を算定し て破壊率を求める。本来ならば破壊限界を与える流量を 超える流量時には樹木群が破壊された状態での破壊の作 用值の算定を行うべきであるが，本論文ではこの種の解 析の第一歩として樹木に働く流体力の代表值として立木 状態の場合を考えて解析している.

\section{(2) 樹木群が継断方向に存在する場合の検討}

樹木群が縦断方向に存在する場合と存在しない場合に ついて破壊率を検討する。樹木群の密度については, 複 断面水路の小断面内 $\left(10 \times 10 \mathrm{~m}^{2}\right)$ に樹木が 3 本平均的に 存在するとした．図一 10 に縦断方向に樹木が存在する 場合の計画高水流量における地点と破壊率の関係を示す. 破壊率について，倒伏 1 , 抜根 1 は樹木群が縦断方向に 存在しない場合で3. (3). a )節と同值である.倒伏 2 , 抜根 2 は樹木群が縦断方向に存在する場合である.

図一 10 力ら破壊率を各破壊について見ると，ほとん どの地点で同值, あるいは倒伏 1 より倒伏 2 のほうが大 きく, 抜根 1 より抜根 2 のほうが小さくなっている.こ れは, 複断面水路の隣り合う断面の周辺境界のせん断力,

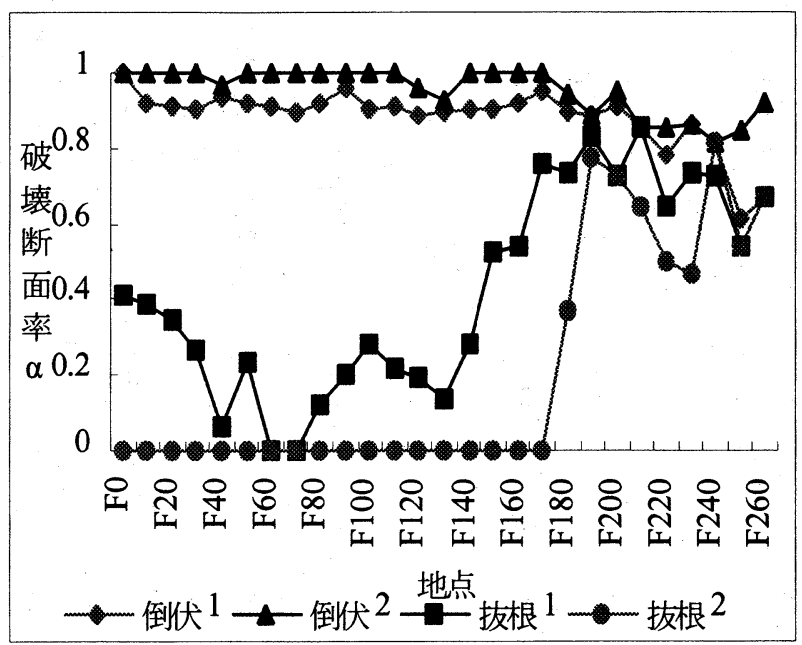

図-10 笛吹川での縦断方向に樹木群が存在する場合

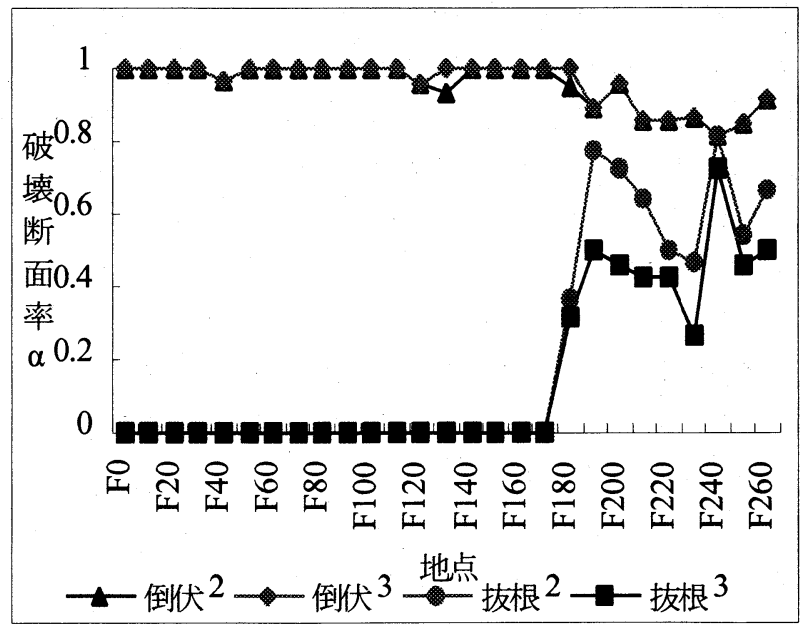

図-11 笛吹川で樹木の密度を変化させた場合

縦断方向の樹木の存在を考慮したことによって, 流速が 遅くなり, 水深が深くなったためであると考えられる. その結果, 流速, 水深に依存している倒伏は, 流水が樹 木の投影面積 $\left(A\left[\mathrm{~m}^{2}\right]\right)$ に占める割合が大きくなり, 倒 伏 2 の破壊率が大きくなる. また, 流速のみに依存して いる抜根は，抜根 2 の破壊率が小さくなる.

\section{(3) 樹木群の密度変化による検討}

樹木群の密度に関係している樹木の本数を変化させて, そのときの破壊率について検討する. 樹木の本数は疎の ときがこれまでの検討で用いた 3 本, 密のときが 25 本と した. 図ー 11 に樹木群の密度を変化させた場合の計画 高水流量における地点之破壊率の関係を示す. 破壊率に ついて, 倒伏 2, 抜根 2 は樹木群の密度が疎のときで, 倒伏 3 , 抜根 3 は樹木群の密度が密のときである.

図一 11 から，倒伏の破壊率は，樹木群の密度が密に なったことにより, 小断面内の流速は遅く, 水深は深く なるが，式（1）から流速と水媣との相互の影響のため, ほとんどの地点でほぼ同一であった。逆に, 抜根の破壊 


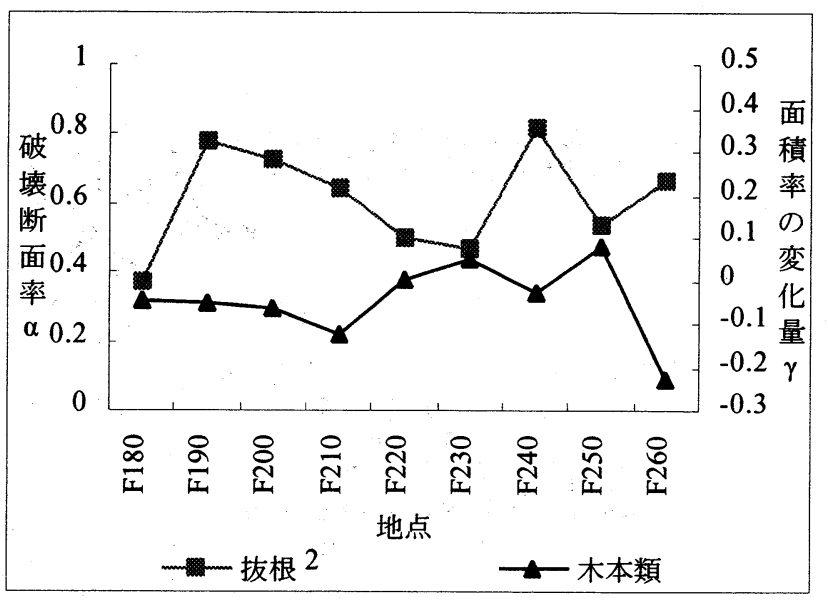

図-12 笛吹川での破壊率・面積率変化量の流下方向の変化

率は，樹木群の密度が密になった影響を受けて式 (2)の 流速が遅くなり,抜根 2 と抜根 3 の間で差が笛吹川の上 流域で見られた。これから抜根においては，樹木群の密 度が破壊率に影響を及ぼすことがいえる。

これらの検討で，さらに実際の河川の状況における樹 木の破壊の解析が可能となった。しかし，この解析では 実河床横断面のすべてが植生域であり, 非植生域が存在 せず澪筋にも樹木を存在させている.今後の課題として, 植生域，非植生域がともに存在するときの流況及び破壊 率の変動を検討する必要がある。

\section{(4) 航空写真による観測值との間接的比較}

出水前後の航空写真を用いて, これまでの解析で得ら れた破壊率と実河川の木本類面積率の変化量 $(\gamma$, 以降 簡単に「変化量」と呼ぶ）を比較する．ここで検証する 破壊率は, 河床横断面の形状で低水路々高水敷が明確で なく, 起伏の小さい上流域における設定した樹木の密度 が実河川に近い状態であると考えられる抜根 2 である. また, 航空写真は’ $97, ' 98$ 年に撮影されたもので, この 期間は出水が多かった時期でもある。 そのため変化量は 減少傾向にある. また変化量については航空写真の判読 によるもので, 単位河道当たりの河道面積に対する木本 類面積の割合の 1 年間における変化量である．河道面積 とは植生，河及び裸地の面積の和である ${ }^{11)}$.

図-12 に地点と破壊率, 変化量の関係を示す. 図一 12 から破壊率と変化量の関係について, 破壊率が高い 地点では変化量が負の值を, 破壊率が低い地点では変化 量が正の值をとっている．また，上流域全ての地点では ないが, 地点における破壊率と変化量の変動が対称とな っている. したがって, 河床横断面の形状にもよるが, 破壊率の高い地点では出水が起こると木本類が破壊され て面積率が減少し, 破壊率と変化量の相関性がある.

\section{5. 結論}

河道内樹木の破壊形態のうち，平均的な流れに支配 されると思われる代表的な破壊として, 倒伏と抜根の場
合についていくつか検討を行った. その結果,

（1）破壊断面率は河道特性, 樹木密度によって変化 し，特に，抜根による破壊はこれらの影響を大 きく反映して, 同じ樹木の場合河川上流ではよ り破壊が生じやすいこと.

（2）笛吹川で調查された破壊による木本類面積率 の減少の傾向を計算による破壊断面率の変化の 傾向と比較的よく一致し，ここでの推定方法が 大枠で妥当なものとなっていること.

などが示された，当初の方針から，本研究では単純・ 典型的なパラメータが用いられて破壊の程度が算定 されているが，実務上はさまざまな現地資料に基づい て「分布されたパラメータ」のもとに，限界の「範囲」 を与えるような取扱がより適切と考えている. 今後も 検討を重ねていく予定である.

謝辞 : 本研究の一部は平成 10,11 年度 (財) 河川環境管 理財団「河川整備基金」研究助成金の支給を受けて行わ れたもので，ここに記して感謝の意を表します。

\section{参考文献}

1）河川環境管理財団 : 河川の植生と河道特性, 河川環境総 合研究所資料第 1 号, 1995.

2) 辻本哲郎 : 手取川扇状地区間の河原の植物群落と河道特 性, 金沢大学日本海域研究所報告, 第 25 号, pp.83-99, 1993.

3) 岡部健士，鎌田磨人, 湯城豊勝, 林雅隆 : 交互砂州上の 河状履歴の相互関倸一吉野川における現地調查一, 水工 学論文集, Vol.40, pp.205-212, 1996.

4）砂田憲吾, 岩本尚, 松崎実 : 河川植生の水平・鉛直分布 と河道特性に関する調查解析, 水工学論文集, Vol.40, pp.193-198, 1996.

5) 荻住 曻: 樹木根系図説, 誠文堂新光社, pp.101-114, 1991.

6)，渡邊康玄，三谷修司：鵡川 KP14.1 KP15.2 における河道 内植生の変遷と平成 4 年 8 月洪水による河道内樹木の倒 伏状況調查, 開発土木研究所月報, No.483, pp.55-69, 1993.

7) 石川忠晴 : 水制と灌木が一体となった半自然的河川構造 物に関する基䃈的研究，平成 4 年度科学研究費補助金研 究成果報告書, pp.5-61, 1994.

8）建設省河川局治水課：河道内樹木の伐採・植樹のための ガイドライン (案), 山海堂, pp.20-35, 1994.

9) 池田駿介, 泉 典洋: 浮遊砂の横断方向拡散係数につい て, 土木学会論文集, No.434/II-16, pp.47-55， 1991.

10）富永晃宏, 長尾正志, 劉 健, 鈴木徹也 : 洪水流の抵抗 と流れ構造に及ぼす高水敷樹木群の配置の影響, 水工学 論文集, Vol.39, pp.477-482, 1995.

11) 飯田祥二, 砂田憲吾, 西木卓司 : 河川植生域の経年変化 の予測手法について, 土木学会第 55 回年次学術講演会講 演概要集, II-141，2000.

(2001.10.1受付) 